\title{
Diving deeper: ways to improve the early identification of young clients with disordered eating in rural areas
}

\author{
Deanne Harris ${ }^{1 *}$, Lisa Staples², Kathryn Penman ${ }^{1}$, Helen Carter ${ }^{1}$, Leanne Brown ${ }^{3}$ \\ From 2015 ANZAED Conference: Riding the Waves to Recovery \\ Surfers Paradise, Australia. 21-22 August 2015
}

Connections with a local mental health service for young people, headspace, led to collaboration between local health service dietitian's and headspace staff. This partnership enables early detection and treatment of young people with disordered eating in Tamworth NSW.

A project identified the need to enhance staff awareness of nutrition and disordered eating, improved management of young people with disordered eating and streamlined referral processes to local dietitians. Specific education was conducted for headspace, Tamworth staff about food, mood and body image in young people. Staff then attended formal training in identifying and assessing eating disorders.

Staff identified the development of a dietetic service for disordered eating, as a priority for headspace, Tamworth. Standard intake forms were adapted with more detailed questions about intake and attitudes to food and body image. Referral processes to dietitians were improved and referral numbers increased markedly. The demand for eating disorder specific dietetic services led to funding for an on-site dietitian one day per week. Dietitian led monthly clinical case review, staff inservices and young person cooking skills classes have all commenced since the service began.

Improved screening and referral processes have identified the need to 'dive deeper' into nutrition for this target group.

\section{Authors' details}

${ }^{1}$ Hunter New England Health Local Health District, Newcastle, Australia. ${ }^{2}$ Headspace, Australia. ${ }^{3}$ University of Newcastle Department of Rural Health Tamworth, Tamworth, Australia.

* Correspondence: deanne.harris@hnehealth.nsw.gov.au

${ }^{1}$ Hunter New England Health Local Health District, Newcastle, Australia

Full list of author information is available at the end of the article
Published: 23 November 2015

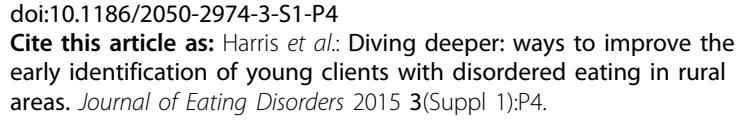

Cite this article as: Harris et al: Diving deeper: ways to improve the early identification of young clients with disordered eating in rural areas. Journal of Eating Disorders 2015 3(Suppl 1):P4.

Submit your next manuscript to BioMed Central and take full advantage of:

- Convenient online submission

- Thorough peer review

- No space constraints or color figure charges

- Immediate publication on acceptance

- Inclusion in PubMed, CAS, Scopus and Google Scholar

- Research which is freely available for redistribution 